
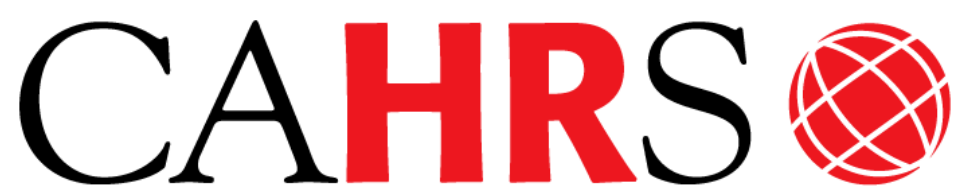

Center for Advanced Human Resource Studies

Worhing Paper gealeg
CAHRS / Cornell University 187 Ives Hall

Ithaca, NY 14853-3901 USA

Tel. 607 255-9358

www.ilr.cornell.edu/CAHRS/

\title{
Organization-wide Broad-based Incentives: Rational Theory and Evidence
}

Janet $\mathrm{H}$. Marler

George T. Milkovich

Yoshio Yanadori

Working Paper 02 - 05

CORNELL illr school of Industrial and Labor Relations 


\title{
Organization-wide Broad-based Incentives: Rational Theory and Evidence
}

\author{
Janet H. Marler \\ Assistant Professor of Management \\ School of Business \\ State University of New York at Albany \\ 1400 Washington Ave \\ Albany, NY 12222 \\ 518-442-4966 \\ marler@albany.edu \\ George T. Milkovich \\ Catherwood Professor of Human Resource Studies \\ ILR School \\ Center for Advanced HR Studies \\ Cornell University \\ Ithaca, NY 14853 \\ gtm1@ cornell.edu \\ Yoshio Yanadori \\ ILR School \\ Cornell University \\ Ithaca, NY 14853 \\ yy40@ cornell.edu
}

September 4, 2002

http://www.ilr.cornell.edu/cahrs

This paper has not undergone formal review or approval of the faculty of the ILR School. It is intended to make results of Center research available to others interested in preliminary form to encourage discussion and suggestions. 


\begin{abstract}
Despite the widespread use of incentive pay, there is limited evidence about what factors influence its organization-wide, broad-based application. This study uses data from three sources and multiple levels, including a unique data set of the total compensation of individual employees in 104 firms over a four-year period (1997-2000), and theoretically and empirically examines the use of bonuses and stock options in organization-wide applications. We examine the efficacy of three main rational theories, principal-agency, positivist agency and contingency theories, which are based on the premise that incentives are related to performance. At the individual level we identify two determinants: type of job and level within the hierarchy and four determinants at the organizational level: performance, risk, size, and strategy. Our results indicate that the factors derived from the three theories provide a limited explanation for the variation in the use of broad-based incentives within and across organizations.
\end{abstract}

KEY WORDS: Compensation; Incentives; Variable Pay 


\section{Organization-wide Broad-based Incentives: Rational Theory and Evidence}

The use of variable pay has grown in popularity over the past decade with $67 \%$ of companies offering some form of variable compensation to employees below the executive level (Abosch 1998). Despite its widespread use, however, there is limited evidence about what factors influence the use of broad-based (i.e., over $50 \%$ of employees eligible) variable pay. While the rhetoric in the professional literature assumes that performance-based incentives improve organizational performance, the scholarly literature is less affirmative. At the CEO level, several studies report a causal relationship (Mehran 1995; Finkelstein and Boyd 1998; Anderson, Banker et al. 2000). However, others remain skeptical about causation in the pay performance relationship for CEOs (Hall and Murphy, 2000). Below the level of senior executive, theory and evidence suggests that in addition to causal ambiguity, widespread use may not be effective in all cases. Gerhart and Milkovich's (1990) and Abowd's (1990) longitudinal studies of managerial compensation in Fortune 500 organizations suggested that companies paying a higher proportion of variable pay to base salary, also had higher subsequent financial performance, however, these results varied depending how performance was defined (Abowd, 1990) and whether the company was historically profitable (Gerhart \& Milkovich, 1990). Other researchers have found that variable pay's effectiveness depends on the risk of the organization's earnings stream (Garen, 1994;Bloom \& Milkovich, 1996; Aggarwal \& Samwick, 1999), level of monitoring (Beatty \& Zajac, 1996; Gray \& Cannella, 1995) or fit with business level strategy (Boyd \& Salamin, 2001;Montemayor, 1996;Gomez-Mejia \& Balkin, 1992).

Both researchers and practitioners have interests in understanding the application and efficacy of using broad-based incentives. This goal, however, is challenging for two reasons. The first is that different theories often offer somewhat different interpretations about how the incentive compensation-organization performance relationship works. Even rationally based theories whose premise is that better compensation practices result in better organizational 
performance differs. For example, agency theory arguably the dominant rational theory with respect to this topic, has developed along two lines: positivist and principal-agent (Eisenhardt, 1988; Beatty \& Zajac, 1994). While the two streams share common assumptions about people, organizations and information, they differ in their focus and in their dependent variable (Eisenhardt, 1988). Principal agent-theory focuses on the incentive effects of variable pay and the reduction of agency costs as the path to improved shareholder performance. Positivist agency theory suggests that monitoring rather than incentives may be more cost effective, particularly when the use of incentives shifts too much risk to the individual or when outcomes are not easily measured. Contingency theory, another theory widely used to explain compensation-organization performance, focuses on the alignment of a bundle of compensation practices that support the company's overall strategy. Accordingly, organizational performance may be related not simply to variable pay but to how well total compensation, which includes all components of pay, "fits" with the organization's strategy (Gerhart, 2000; Montemayor, 1996; Gomez-Mejia and Balkin, 1992). Typical in this vein of research, Gomez-Mejia and Balkin (1992) found that different bundles of 13 forms of compensation fit two different organization strategies, which they labeled algorithmic and experiential.

The second reason research on broad-based incentives is challenging is that publicly available compensation data below the executive level is difficult to obtain. And more often than not, the data are very limited, omitting important forms of total compensation (e.g. stock options or benefits).

The purpose of our study is threefold. First we build on the basic insights of principalagent theory, positivist agency theory, and contingency theory to derive a set of multi-level factors that, based on theory, should influence variable pay in broad based, organization-wide applications. We focus on these three theories because each shares the basic premise that the use of organization-wide variable pay is related to organizational performance Second, our data are more recent (1997-2000) and more comprehensive (e.g. includes short-term and longterm stock options) than previously published works of broad-based variable pay and permit us 
to consider variable pay as part of total compensation (base, bonus, and long-term incentives). Finally, we leverage the multi-level nature of our data, employees nested in over 100 organizations, to gain a more precise understanding of the interactions and effects of individual and organizational differences on an individual's incentive compensation.

\section{Principal-Agency Theory}

In the traditional application of principal-agent models, performance sensitive pay provides a viable solution to the problem of aligning the interests of managers with those of the owners of the corporations they manage (c.f. Ross, 1973;Lazear, 1979;Grossman\& Hart, 1983; Hart and Holmstrom, 1987; Eisenhardt, 1988; Murphy, 1999). Countless studies empirically support this prediction (See Murphy, 1999 for a review). It is important to note, however, that these studies merely establish a significant and positive relationship between executive compensation and changes in firm value and not causal direction. Few studies focus on whether the introduction of these incentives leads to better firm performance. This is simply assumed in the theory although the few studies that have attempted to test this empirically do find a positive relationship between subsequent organizational performance and the proportion of performance contingent compensation in an organization's pay mix (Abowd, 1990; Gerhart \& Milkovich, 1990, Leonard, 1990; Tosi \& Werner, 1995; Montemayor, 1999). These studies, however, lacked data on long-term equity based incentives and only tested this relationship with respect short-term incentives as a proportion of pay. Consequently, applying the same rational as previous studies of variable pay but expanding it to include both short-term and long-term incentive pay, we hypothesize that:

Hypothesis 1a: Organizational performance is related to the use of variable pay. Higher performing organizations are more likely to pay more variable compensation than poorer performing organizations.

Before the 1990s, long term incentives were used sparingly and primarily only for senior executives (Abosch, 1998) consequently expanding the scope of the inquiry was not an empirical issue. In the past decade, however, the practice of compensating CEOS, senior 
executives and even managers below senior executive ranks with stock options and other forms of long-term incentives has risen dramatically (Abosch, 1998; Kruse et al, 2000). Principalagent theory provides the rational for doing this. Performance sensitive pay aligns the interests of all levels of employees with the interests of shareholders. We therefore hypothesize that we should see a performance sensitive relationship applied throughout the organization.

Hypothesis 1b: Higher performing organizations pay more variable compensation throughout the organization than poorer performing organizations.

With the increasing size and prevalence of long term incentives, recent studies have shifted away from the performance contingent relationship and focused instead on understanding the effects of the increasing risk and the uncertainty associated with stock options, the typical form of long-term compensation. In general, principal-agent theory predicts a negative correlation between the riskiness of firm-level performance and use of performance contingent pay (Garen, 1994; Samwick \& Aggrwarl, 1999). Garen found that CEO total compensation was negatively related to the organization's measure of unique variance after controlling for variance related to the market. Even stronger evidence is provided by Aggarwal \& Samwick who showed that the variance in CEO and top executives' total compensation is negatively related to the degree of variance in the organization's stock returns. Thus the larger the variance in total stockholder returns the lower the variability in total compensation. Both these studies, however, only look at the relationship with respect to CEO and top executives who are likely to exert much greater influence on the organizations' performance than managers below this level.

The principal agent model does not differentiate between employee levels within the organization. The main component of interest is whether and to what extent the variance in organizational performance influences the optimality of the pay- organization performance relationship. Virtually no attention is paid to variance in individual's risk aversion or perception of the riskiness of the firm's performance. Yet, expectancy and attribution theories (Deci, 1997; 
Bartol and Locke, 2000) both suggest that the degree to which individuals perceive control over the outcome on which their rewards depend significantly influences their behaviors. Tests of the principal-agent theory focus on riskiness at the firm level such as variance of the overall firm's performance and variability beyond the control of the firm (Bloom \& Milkovich, 1996). However, other forms of risk include the instrumentality individuals perceive in the variable pay performance relationship. Arguably, below the CEO and senior executives the degree of uncertainty is likely to be much greater. Hence, we expect that the relationship between variable pay and organization performance to be more attenuated for employees below CEO and senior executives within a given company. Further, for employees within organizations with greater performance variability we would expect there to be an even greater attenuation as the employee's level within in the organization declines.

We state our hypotheses to reflect the two levels at which we expect to see these relationships exhibited. First, within organizations, we expect to see a relationship between job level and variable pay.

H1c: The proportion of variable pay to base pay within an organization will vary with job level. The lower the jobs level the lower the proportion of variable pay.

Second, across organizations, we expect to see a negative relationship between overall organizational performance variability and the use variable pay, consistent with recent findings for CEO incentives (Garen, 1994; Samwick \& Aggrwal, 1999) but for variable pay at the middlemanagement level.

H1d: Across organizations, the degree of variability in organizational performance is negatively related to the proportion of broad-based variable pay to base paid, even after controlling for individual differences within organizations on human capital and job attributes.

Our last hypothesis captures an expected interaction between levels of analysis. Thus, within organizations there is an effect of distance and less instrumentality with respect to 
organization-wide performance and this is intensified by the degree of organization-wide performance variability. We therefore assert:

H1e: The degree of variability in organizational performance interacts with job level such that organizations with higher levels of performance variability will have lower variable pay at lower job levels.

\section{Positivist Agency Theory and Monitoring}

A major assumption in agency theory is that the employee's actions cannot be observed or are costly to observe (Abowd, 1990). This may be true under certain circumstances: nonprogrammable jobs, rapid growth, disbursed ownership. But where monitoring and observing actions of employees is possible, monitoring as in providing supervisors, may be less costly and therefore preferable to more risk prone variable compensation. Beatty \& Zajac (1995) found that small emerging growth firms, for example, appeared to substitute monitoring by outside members of the board of directors for significant non-cash incentives to its top management executives. Drawing from positivist agency theory, they argued strong monitoring is appropriate when the benefits of monitoring outweigh the costs associated with using managerial incentives, particularly when incentives are only weakly tied to firm performance, which is often the case in highly uncertain business conditions. Beatty \& Zajac tested their propositions, however, only using CEO and senior executives from a sample of IPOs.

Some work has been done on the cost versus benefits of variable pay compared to monitoring at levels below senior executives and CEOs (c.f. Welbourne and Gomez-Meija 1995). Principal-agency theory suggests that incentive effects are diminished even more for managers who see firm level performance measures as extremely noisy measures of their individual performance. Baker (1997) mathematically demonstrated that the use of noisy measures of performance does significantly diminish incentive effects of performance contracts. Further, highly variable firm-level outcomes such as profitability and stock price provide very little information about the quantity and quality of individual managerial performance (Eisenhardt 1989). Consistent then with theory, we would expect that below the senior executive ranks, 
greater monitoring through levels of managerial oversight would be more effective in eliciting superior behavior than simply aligning interests through outcome-based compensation. Rather than oversight from a governance structure, however, oversight resides in the organizational structure. Managerial hierarchy, a device particular to organizations as opposed to external markets(Williamson 1981), is effectively used for monitoring and controlling behavior. In larger bureaucratic organizations where there is a managerial infrastructure to support greater monitoring and less need to deploy higher cost incentives, it likely that use of performancebased incentives is less efficient than simply monitoring performance and rewarding greater effort with short-term individually based increases to base pay such as merit increases. We therefore predict based on this theoretical perspective:

H2a: The greater the levels of firm monitoring, as represented by levels of management between the manager and CEO and size, the smaller the proportions of variable to base pay.

While the Board of Directors may closely monitor the CEO and top managers, not all jobs below this level may be easily monitored. In the case of especially skilled positions that are not as programmable or where productivity is not easily evaluated, observation of behavior is not a reliable indicator of performance (Eisenhardt 1989). For example, $R \& D$ jobs compared to general management positions may not be as easily monitored. In this case out-come based measures are warranted and are less costly and more effective than monitoring. As a consequence, the type of job may also bear on whether monitoring is as effective as incentives.

H2b: Middle managers in technical jobs are more likely to exhibit a greater level of variable to base pay compared to other middle managers.

Managers in smaller firms, with fewer levels of management, are likely to have a closer line of sight than managers in much larger firms and are likely to have more influence on outcomes than larger firms. Thus in addition to number of layers of management and types of jobs, the size of the organization should influence the efficacy of incentive compensation. 
Individuals in larger organizations may perceive they have less individual effect on organizational outcomes, which may also encourage free riding. Thus we expect:

H2c Across organizations, large organizations will exhibit a lower proportion of variable pay to base pay than small organizations, controlling for within organization differences in human capital and job characteristics.

\section{STRATEGIC CONTINGENCY THEORY}

In addition to uncertainty and organizational bureaucracy, business strategy also influences both compensation design and organizational performance. Strategic contingency theory holds that firm performance is based upon the alignment of an organization's compensation systems and business strategies (Milkovich 1988; Gomez-Mejia and Balkin 1992). Gerhart \& Milkovich (1992) analyses of a multi-industry sample of public companies over a 5-year period from 1980 to 1985, provided some indirect empirical support for this theory, finding that organizational differences in pay mix practices explained an additional $20-35 \%$ variance in compensation even after controlling for factors such as industry, size and profitability and differences human capital. However, they did not directly measure business strategy. Building on these results, using a more recent cross-sectional sample of multi-industry firms, Montemayor (1996) linked specific business-level strategies to specific types of compensation strategies identified in the strategic human resource literature. In partial support of the underlying contingency framework, Montemayor reported that higher performing firms had specific compensation strategies and that these distinguished them from lesser performing firms. The basic premise of this research is that certain combinations (or "bundles") of compensation policies better support the firm's strategic business objectives.

One particular strategy that has gained currency in the nineties is the risk sharing formula characterized by below market base pay levels offset with a premium of higher variable pay such as stock options (Chingos 1997). From a strategic perspective, such a risk sharing strategy might both improve earnings and lower earnings variability because it lowers an organization's fixed compensation costs. If sales volumes vary significantly, the bottom line is 
less affected because compensation costs vary as well. Thus for emerging firms in relatively new and untested product markets, this is an appealing design. Low fixed costs along with variable pay to increase/ reward employee effort. Also a risk sharing strategy is consistent with firms emphasizing cost efficiencies as the basis of competitive positioning with their industry (Porter 1985). Thus based on this pay contingency line of reasoning, we predict:

H3: Emerging growth firms will have compensation characterized by a high proportion of variable pay to base pay compared to other firms.

\section{Integrating Principal Agent and Strategic Contingency Theories}

In general, principal agent theory predicts that greater incentive compensation reduces agency costs by aligning executive interests with the interests of shareholders. A risk sharing strategy seems to be justified, at least on these grounds, in the business press. On the other hand, principal agent theory also specifies a risk- return trade-off. In cases where the firm's earnings are highly variable, a higher proportion of variable pay may not be optimal because as discussed earlier, theory and evidence suggests too much uncertainty can offset the incentive effect. Too much uncertainty associated with the realization of outcome-based incentives can cause agents to reduce effort or to take costly actions designed to reduce the variability of their pay (Bloom \& Milkovich, 1996; Werner \& Tosi, 1995; Eisenhardt, 1989). Bloom \& Milkovich (1996) study of compensation design in large Fortune 500 companies in the mid eighties, found evidence suggesting that organizations with higher levels of organizational risk and greater use of incentive pay also had lower shareholder returns.

Risk sharing strategies have often been coupled with a strategy of smaller emerging firms who have limited current resources but whose future earning is premised on business strategy for growth (Chingos 1997). A hallmark of these firms however is the variability of performance and therefore principal agent theory would predict that these firms should use less variable pay. From a contingent strategic perspective, Montemayor theorized that these kinds of organizations, he labels innovators, should evidence supportive compensation policies that 
comprise both high base pay and high variable pay. Total compensation would indeed be higher with these firms, but with less earnings risk to the employee. This combination of high total compensation comprised of above average base pay and an opportunity to share in the profits of the firm are also characteristics of the best practice compensation strategy described by others (Huselid 1995; Pfeffer and Veiga 1999) that are based on the resourced-based view of the firm (Barney 1991). Thus when the predictions of both principal agent theory and the strategic - contingent view of the firm are combined, we predict an alternate compensation design to the one based on competitive strategy alone.

H4: Emerging growth firms are less likely to have a high proportion of variable pay to base salary than older established firms.

\section{Monitoring and Business Strategy}

Beatty \& Zajac (1994) reported that board monitoring clearly replaced incentives as the preferred compensation strategy for CEOs in a sample of IPOs. However, for individuals below this level the dynamics of monitoring, incentive instrumentalities and individual motivation may vary. While emerging growth organizations may use greater monitoring as a means to offset the incentive risk trade-off, there are other aspects of organizational structure and individual motivation that may moderate efficacy of these factors. Employees in smaller firms with fewer organization levels are likely to have a closer line of sight than individuals in much larger organizations and are likely to have more influence on outcomes than larger organizations. Furthermore, while the board may closely monitor the CEO and top managers, not all jobs below this level may be easily monitored. Certain especially skilled positions may not be as programmable or easily monitored (Eisenhardt 1989). For example, in highly sophisticated R \& D jobs observable behaviors are not easily specified. Further, in emerging firms whose strategy for success is based on innovation, $R \& D$ jobs are highly important. As a consequence, in addition to the level of monitoring associated with the job type, the type of business strategy should also affect compensation design. 
H5: Organizational strategy moderates the proportion of variable pay to base pay such that those managers in highly technical jobs in emerging growth organizations will exhibit greater levels of variable pay to base pay compared to companies pursuing different organizational level strategies.

\section{METHODS}

\section{Sample}

To test these propositions, we use compensation and performance data from a population of high technology firms. These organizations include large well-established organizations as well as newer emerging growth firms. Data for the study come from four archival data sources. Total compensation data are drawn from the Clark/Bardes, formerly known as Executive Alliance SC/ChiPS, annual compensation surveys of over 140 high technology companies over a four-year period, 1997 through 2000. The database contains company pay policy data, individual pay, job and demographic information for a sample of managers from each participating company. The individual pay information includes base salary, short-term incentives, equity-based compensation incentives, job level, and job family. These data are also merged with financial accounting data drawn from COMPUSTAT data files and other information are gathered from the CD Disclosure database and SEC filings on Edgar. The final sample consists of 104 organizations for which we had complete information. We tested this final sample against the original sample to see if there were significant differences in average variable compensation, profitability and size and found no significant biases.

\section{Measures}

\section{Individual Level Measures}

Base salary represents an employee's annual salary as of April 1, 1997 and 2000.

Variable compensation includes both short and long term incentives. The value of shortterm incentives is equal to the actual gross awards distributed during the prior 12-month period ending April 1, 1997 and April 1,2000. Short-term incentives include all cash awards related to annual corporate, division, unit or individual performance and profit sharing payments. In 
addition to cash awards, the values of stock grants and restricted stock awards with vesting schedules of less than one year are included in the value of short-term incentives. These stock values represent the face value of the stock at grant (i.e. the fair market value of the stock multiplied by the number of shares granted.). Long term incentives include individual valuations of incentive stock options, non-qualified stock options, stock appreciation rights, restricted stock awards with more than one year vesting, performance units and performance shares. All valuations reflect the dollar amount an investor would deem equivalent to the value of the award, considering the expected future price of the stock, the time value of money, and the associated risk. For options, the Black-Scholes Option pricing model is used. Long-term incentive valuations are also adjusted to reflect the frequency of grants.

Tenure is the reported years of service of the employee as of April 1 of the reporting year.

Level represents the degree of responsibility, task complexity, education and years of work experience required for a job. There are five levels of jobs for individual contributors, jobs where there are not supervisory responsibilities and three levels of managers. Higher levels of manager represent responsibility for increasing number of employees and cross-functional representation.

Job Type describes the primary nature of the work. There is three job types: research and development (R\& D), technical and non-technical. Job Type is coded as a dummy where 1 equals research and development and 0 indicates the remaining two categories.

\section{Company Level Measures}

Organizational performance is measured as return on average assets (Abowd 1990; Gerhart and Milkovich 1990; Montemayor 1996) and represents the profit before interest and taxes that the organization derives from managing its business assets. It is derived from COMPUSTAT data for the fiscal year ended prior to April 1 of the year in which the compensation data are collected, in this case for fiscal years ended 1996 and 1999, and 
calculated by dividing operating profit after depreciation by the average of beginning and ending fiscal year total assets.

Size of the company is measured by the total assets of the company. There are several acceptable measures of size including number of employees and total sales. All three measures are highly correlated. We chose total assets for parsimony. The results do not vary if other measures are used.

Organizational risk is measured as the coefficient of variation for return on shareholder equity. The coefficient of variation standardizes variation units across firms of all sizes and is calculated by dividing the standard deviation of return on shareholder equity as measured by Compustat over a minimum of a three year period by the mean of return on shareholder equity over the same period. We use the coefficient of variation of return on shareholder equity as a measure of variation in firm level performance (Gerhart and Trevor 1996) and the extent to which environmental uncertainty impacts firm performance (Gomez-Mejia and Wiseman 1997) in addition to managerial strategic decisions and actions (Ruefli, Collins et al. 1999). This measure of risk was selected from a review of risk studies that summarizes recent methodological findings and identifies coefficient of variation of company level return on investment ratios as one that is more consistent with an understanding of risk from a strategic management perspective than measures taken from financial economics based on capital asset pricing theory (Ruefli, Collins et al. 1999).

Organizational strategy is based on a content analysis of the firm's description of their business, competition and marketing strategies described in the organizations $10-\mathrm{K}$ filing for the fiscal years ended in 1996 and 1999, the performance years represented in the study sample. Four subject matter experts read through these descriptions and indicated whether they thought the organization's goals and objectives could be characterized as shrinking, retrenching, focused on stabilized incremental growth or aggressive growth (Gomez-Mejia and Balkin 1992). To insure reliability of these assessments the assessments of all four-subject experts were analyzed for consistency. Inter-rater reliability on a sample of $810-\mathrm{K}$ evaluations was assessed 
after each rater was trained how to complete a standardized evaluation form. Inter-rater reliability for this sample was .75 . Each of the four possible organizational-level strategies were then coded as dummy variables.

Age is the number of fiscal years in operation from the date of incorporation.

Year is a control indicator variable representing the fiscal year for which the financial data are reported. In this case it is 1996 and 1999.

\section{Hierarchical Linear Model Specification}

To analyze our data, we use a hierarchical linear model (HLM), adopting a two level approach (Bryk and Raudenbush 1992) where the level- 1 model (employees) is estimated separately for each company (level-2). Bryk \& Raudenbush (1992) summarize the methodological advantages of using HLM for multi-level data as capturing the best features of individual (level-1) and company (level-2) analyses, "It provides unbiased and efficient estimates of the fixed effects, which are more closely approximated by the Level-1 analysis, and provides proper standard error estimates, regardless of the degree of within- unit clustering, that are more closely approximated by the Level-2 analysis (p.84)." A second advantage of using HLM is that it allows for a proper examination of heterogeneity both between individuals within an organization and heterogeneity across organizations. With HLM we can manage this empirical issue appropriately by recognizing the effects of both individual-level and organizational-level on the dependent variable. HLM enables us to estimate a separate set of regression coefficients for each organization and then to model variation among organizations in their sets of coefficients as multivariate outcomes to be explained by organizational factors (Bryk \& Raudenbush, 1992).

\section{Statistical Multi-level Model}

Our model of these three theories involve studying both individual and organizational differences and takes a multi-level form, where on one level, level-1, we study individual differences within organizations and our dependent variable is at the individual level:

Level-1: $\gamma_{i j}=\beta_{0 j}+\beta_{n j} X_{n i j}+r_{i j}$ 
Where $\gamma_{i j}$ is the outcome measure for each individual. In this analysis $\gamma_{i j}$ represents the proportion of variable pay to base pay, measured as short variable pay to base pay, long-term variable pay to base pay, and total variable pay to base pay for individual $i$ in company $j, X_{n i j}$ is a matrix of independent variables representing human capital and job attributes in company j, $\beta_{0}$, and $\beta_{\mathrm{nj}}$ and are intercepts and slopes estimated separately for each company and $r_{\mathrm{ij}}$ is the residual representing the remaining unexplained variation across individuals in the sample of companies.

On the second level, the effect that the company differences exert on the individual model is captured as follows:

Level 2: $\beta_{0 j}=\gamma_{00}+\gamma_{0 k} G_{k j}+U_{0 j}$

$$
\beta_{n j}=\gamma_{n 0}+\gamma_{n k} G_{k j}+U_{n j}
$$

where $G_{j}$ are the company level variables, and $\beta_{0 j}$ are intercepts and slopes relating company level variables to the intercept, $\beta_{0 \mathrm{j}}$ and slope terms, $\beta_{\mathrm{nj}}$, from the level -1 equation and $\mathrm{U}_{0 \mathrm{j}}$ and $\mathrm{U}_{1 \mathrm{j}}$ are the level -2 residuals (Hoffman 1997).

To test hypotheses $1 \mathrm{c}$ and $2 \mathrm{~b}$ we specify basic level-1 ordinary least squares regression with random coefficients and robust error estimation:

$$
\begin{aligned}
& \operatorname{LTI}_{i j}=\beta_{0 j}+\beta_{1 j}\left(\text { Tenure }_{i j}\right)+\beta_{2 j}\left(\text { Type }_{i j}\right)+\beta_{3 j}\left(\text { Level }_{i j}\right)+r_{i j} \\
& \text { STI }_{i j}=\beta_{0 j}+\beta_{1 j}\left(\text { Tenure }_{i j}\right)+\beta_{2 j}\left(\text { Type }_{i j}\right)+\beta_{3 j}\left(\text { Level }_{i j}\right)+r_{i j}
\end{aligned}
$$

Where $\mathrm{LTI}_{\mathrm{ij}}$ is the individual level outcome, measure the proportion of long-term incentive to base salary for individual $\mathrm{i}$ in company $\mathrm{j}$, and $\mathrm{ST} \mathrm{I}_{\mathrm{ij}}$ the proportion of short-term incentive to base salary. Tenure, Job type, and Job level are independent values centered on their grand mean for each individual in the sample. $\beta_{0}, \beta_{1 j}, \beta_{2 j}$ and $\beta_{3 j}$ are random intercepts and slopes estimated separately for each company and $r_{i j}$ is the robust error residual for individual $\mathrm{i}$ in company j.

For the remaining hypotheses we test multi-level effects, using company level variables to examine the effects of company-level variables on individual-level outcomes: The effect that 
the company variables exert on the individual-level model is captured in the level-2 model where estimated Level-1 intercept, $\beta_{0}$, and slopes, $\beta_{1 \mathrm{j}}, \beta_{2 \mathrm{j}}$ and $\beta_{3 \mathrm{j}}$, are level -2 outcome variables.

\section{Level-1:}

$$
\begin{aligned}
& \operatorname{LTI}_{i j}=\beta_{0 j}+\beta_{1 j}\left(\text { Tenure }_{i j}\right)+\beta_{2 j}\left(\text { Type }_{i j}\right)+\beta_{3 j}\left(\text { Level }_{i j}\right)+r_{i j} \\
& \operatorname{STI}_{i j}=\beta_{0 j}+\beta_{1 j}\left(\text { Tenure }_{i j}\right)+\beta_{2 j}\left(\text { Type }_{i j}\right)+\beta_{3 j}\left(\text { Level }_{i j}\right)+r_{i j}
\end{aligned}
$$

Level-2:

$$
\begin{aligned}
\beta_{0 \mathrm{j}}= & \gamma_{00}+\gamma_{01} \text { (Organizational performance) }+\gamma_{02} \text { (Organizational risk) }+\gamma_{03}(\text { Size })+\gamma_{04} \\
& (\text { Age })+\gamma_{05} \text { (Organizational strategy) }+\gamma_{06}(\text { Age * Organizational strategy })+U_{0 j} \\
\beta_{1 j}= & \gamma_{10}+U_{1 j} \\
\beta_{2 j}= & \gamma_{20}+\gamma_{21}(\text { Age })+\gamma_{22} \text { (Organizational strategy) }+\gamma_{23} \text { (Age * Organizational Strategy) }+ \\
& U_{2 j} \\
\beta_{3 j}= & \gamma_{30}+\gamma_{31} \text { (Organizational performance) }+\gamma_{32} \text { (Organizational risk) }+\gamma_{33}(\text { Size })+U_{3 j}
\end{aligned}
$$

Where organizational risk, size, and organizational strategy are company level measures, $\gamma_{00}, \gamma_{01}, \gamma_{02}, \gamma_{03}, \gamma_{04}$ and $\gamma_{05}$ are level-2 fixed effect intercept terms, $\gamma_{10}, \gamma_{20}, \gamma_{21}, \gamma_{22}, \gamma_{30}$, $\gamma_{31}, \gamma_{32}$ and $\gamma_{33}$ are fixed effect slopes relating company level variables to the intercept and slope terms from the level-1 equation, and $\mathrm{U}_{0 \mathrm{j}}, \mathrm{U}_{\mathrm{nj}}, \mathrm{U}_{2 \mathrm{j}}$ and $\mathrm{U}_{3 \mathrm{j}}$, are level-2 residuals.

The expected results for each hypothesis using this multi-level model are summarized on Table 1. 


\section{RESULTS}

Descriptive statistics of the combined sample are shown on Table 2. The average employee in this sample earned approximately 10 percent of their base pay as short-term variable pay, although there was wide variation from no short-term pay to almost four times base pay. These extremes were even more pronounced for long-term variable pay. On average the long-term incentive compensation in this sample represented a little less than one third of a manager's base pay, however this masks wide variation across individuals and firms. While some individuals received no long-term incentives others received over 50 times their base pay in long-term variable pay. About 84 percent of individuals worked for growth companies that had been in business for about 35 years. About 43 percent of the sample consisted of individuals holding positions in research and development. The results of our multilevel analyses appear on Table 3 for short-term variable pay, table 4 for long-term variable pay.

In the first five hypotheses, we examined the extent to which principal-agent theory alone explained variation in the use of broad-based variable pay practices within and across organizations. Hypothesis 1a stated that higher performing organizations would use variable pay more than poorer performers. This hypothesis was supported for both short-term bonuses and long-term incentives. As shown on table 3, variation in organizational performance was positively related to average bonus pay $\left(\gamma_{01}=.0011 \mathrm{p}<.01\right)$ and on table 4 , the same significant relationship is indicated for long-term incentives $\left(\gamma_{01}=.0059 \mathrm{p}<.01\right)$. In hypothesis $1 \mathrm{~b}$ we expected that the same incentive principles explaining variation across organizations would apply at all levels within the organization. Thus we asserted that higher performing firms would have higher short and long-term incentives than lower performers at all job levels. We found no support for hypothesis $1 \mathrm{~b}$ for either short or long-term variable pay. In fact, our results suggest individuals in lower levels of higher performing organizations earn less in long-term incentives $\left(\gamma_{31}=-.0019 p<.001\right)$ than lower performing organizations. In hypothesis $1 \mathrm{c}$, we asserted that variable pay would decline with job level because individuals in these positions would have less 
instrumentality in affecting performance-based variable pay. Our results confirm this hypothesis for both types of variable pay. On table $3, \gamma_{30}$, which measures the individual level relationship between, employee short-term variable pay and the number of levels the employee's job is from the executive management, is significantly negative $\left(\gamma_{30}=-.0129 p<.001\right)$ and on table 4 , for long-term variable pay $\left(\gamma_{30}=-.077 p<.001\right)$. Hypothesis $1 d$ stated that there should be a negative relationship between performance risk and use of variable pay at the organizational level. We found no support for hypothesis $1 \mathrm{~d}$. On table 4, for long-term incentives, the relationship was negative, as predicted but not significant, and on table 3 , for short-term variable pay the relationship was significantly positive $\left(\gamma_{02}=.0001 p<.001\right)$, the opposite of what principal-agent theory would predict. Finally, in hypothesis $1 \mathrm{e}$, we expected that performance risk would moderate the degree to which variable pay is used on a broad basis. Thus we expected that organizations with higher performance risk would use less variable pay at lower levels. The data support hypothesis $1 \mathrm{e}$ with respect to short-term variable pay shown on table 3 $\left(\gamma_{32}=-.00004 p<.01\right)$ but as shown on table $4, \gamma_{31}$ for long-term variable pay is not significantly different from zero. Variance in shareholders' return on equity does not appear to affect differences in the use of long-term incentives for lower levels across organizations.

Three hypotheses based on positivist agency theory focus on the substitution of managerial oversight for the use of variable pay as an incentive alignment device. Our results support hypothesis $2 \mathrm{a}$, which states that there will be a negative relationship between levels of monitoring and variable pay. The level-1 coefficient, $\beta_{3}$, measuring the relationship between variable pay and number of levels away from the executive level was significantly positive for short and long-term variable pay, the same as is predicted under hypothesis 1a based on principal-agent theory. However, more robust results are obtained for positivist theory because the level-2 coefficient, $\gamma_{33}$, measuring variation in this relationship across organizations of different size also supports hypothesis $2 \mathrm{a}$. On table 3 , reporting the results for short-term variable pay, $\gamma_{33}$ is negative and significant $\left(\gamma_{33}=-.0000001 \mathrm{p}<.05\right)$ and on table 4 for long- 
term variable pay, $\gamma_{33}$ is negative and significant $\left(\gamma_{33}=-.0000001 p<.05\right)$. Larger organizations pay lower variable compensation at lower levels within their organizations than smaller organizations. Hypothesis $2 b$ tests whether certain job attributes, which are hard to monitor are associated with higher variable pay. Our results support hypothesis $2 b$. Individuals in R \& D jobs received a significantly higher proportion of their base pay as variable pay, an average of about 6 percentage points higher in total variable pay. In general, however, hypothesis 2c, which asserted that larger organizations would use variable pay less than smaller organizations, was not supported. Instead, our results suggest the opposite, that larger organizations on average pay more in short-term and total variable pay $\left(\gamma_{3}=.00001 \mathrm{p}<.01\right)$.

Our last three hypotheses looked at the influence of contingency theory and integration with the two neoclassic economic theories. In hypothesis 3, we asserted that emerging growth companies would have a larger proportion variable pay than those of older age and other strategies. Our results provide no support for this assertion. There is no variation in average variable pay, either short or long-term, across organizations of younger age, those with an organizational strategy focused on growth or the intersection of these two. We also found no evidence in support of hypothesis 4 , which posed the opposite assertion. While the relationships were not significant for either hypothesis, the signs of the coefficients for age and the interaction term provided greater support for hypothesis 3 , which suggests that younger growing companies are also more likely to have riskier earnings and also share this risk more with employees by having higher variable pay. Note, however, these results are not significant.

Finally, we looked at whether organization strategy moderates the proportion of variable compensation paid to those in more technical positions. Our results here are mixed. We find that younger companies appear to pay their $R \& D$ managers higher short-term and long-term incentives but the relationship is significant only for short-term incentives. The effect is also very weak. Each 10-year difference in company age amounted to about a .75 percentage point difference in total variable pay to base compensation. 


\section{DISCUSSION}

The growth of broad-based incentive compensation is a notable trend in compensation design. We used three rational theories, principal-agency, positivist agency and contingency theories, to identify which factors might influence the use of broad-based variable pay and applied a multi-level lens to consider jointly both individual and organizational-level variables. At the individual level we identified two factors: type of job and level within the bureaucracy. At the organizational level, there were four factors: performance, risk, size, and strategy. Our results indicate that total variance in variable pay is split between individual-level factors, $30 \%$ for shortterm and $33 \%$ for long-term, and organizational factors, $70 \%$ for short-term and $67 \%$ for longterm. However, we found empirically, that alone and combined that these factors, derived from these three theories, and tested on a sample of organizations that reputably have been the most aggressive in deploying this growing compensation practice, provided limited explanation for the variation within and across organizations particularly for long-term incentives.

In support of principal-agent theory we found organizational performance and broadbased variable pay were positively related, which affirms that higher performing organizations do pay higher incentives than lower performing organizations. However, if we investigate further, this relationship does not hold at lower levels within the organizations. In fact our results suggest that higher performing organizations pay less variable pay at lower levels within their organizations. These results may reflect greater risk faced by individuals at lower levels, also consistent with principal-agent theory.

When we then considered the effect of organizational risk, our results indicated performance risk had no significant effect on the use of long-term incentives, either in explaining variation in use of broad-based long-term incentives across companies generally or variation in its deployment to lower levels across different organization. Hence these results provide little support for the expectation, based on principal-agent theory, that organizations with greater performance risk rely less on incentives because of the cost of risk shifting. In fact, we found higher risk organizations used more short-term variable pay and not less. There was no 
significant difference among higher risk organizations in their use of long-term incentives. To investigate this further, we ran the analysis again, controlling for level of base pay, thinking higher base pay might mitigate overall risk of an individual's compensation. In this case, we found the expected relationship for long-term pay. That is for more risky organizations, longterm incentives were used significantly less on average. These mixed results raise the question about whether the same factors that explain the use of variable pay at the CEO and senior executive level, based on principal-agent theory, apply for broad-based variable compensation. Further research is warranted to determine whether factors other than risk influence the use of broad-based incentives ${ }^{\mathbb{1}}$.

With respect to positivist theory, our results are more convincing. We found that larger organizations substitute greater supervision for incentive pay at lower levels in the organizations. Our results also showed that larger organizations used less variable compensation at lower levels than smaller organizations. This again supports positivist theory. Direct managerial oversight replaced riskier variable pay as the preferred mechanism for reducing agency costs. But we also found that larger companies offset this practice by paying out a higher proportion of short-term variable pay on average, compared to other organizations. In addition, our results indicated that for complex, less programmable jobs incentive alignment replaced monitoring (Eisenhardt, 1989) as asserted in hypothesis $2 b$.

Our tests of contingency theory and variable compensation design provided the least explanatory power. While, we found no significant evidence in support of a combined contingency / principal-agency perspective, our results did indicate younger growing companies appear to rely more on variable pay than other organizations in the sample. While these results were not robust, it is possible with a greater sample of firms these results may yield significant results, therefore further research is merited. We also looked at whether organization strategy moderates the proportion of variable compensation paid to those in more complex but strategic positions. While we found that younger companies appear to pay their $R \& D$ managers higher short-term incentives the difference was relatively inconsequential. Each 10-year difference in 
company age amounted to a difference of about a .2 percentage point in bonus pay to base compensation.

In sum, theory tells us that the use of broad-based variable pay should be influenced by both individual and organizational factors. At the individual level, type of job and level within the hierarchy are two factors and at the organizational level, performance, risk, size, and strategy. Empirically we find individual-level factors are important. Both type of job and level within the organization significantly influence the amount of short and long-term variable pay an individual earns. At the organizational level, for short-term incentives, performance, risk, size, and strategy all influenced the application of short-term incentives. In contrast, only organizational performance explained differences across firms in the use of stock options as long-term variable compensation, and not risk or organizational strategy as rational theories predict.

These results have implications for whether researchers can use rationally based theory to adequately explain compensation design. These theories are based on the premise that maximization of shareholder profits is the primary driver of compensation strategy and design. Our results suggest there are other factors to consider. Other theories that challenge the notion of rational wealth maximization behavior and monolithic aligned goals may provide another avenue for explaining current compensation practices. For example, broad-based incentive compensation practices may be adopted by organizations not simply to encourage goal alignment but to respond to the competitive actions of others, to comply with coercive suggestions of industry consultants, or simply to copy "best practices" (Scott 1992; Levine 1993; Scott 1995; Gerhart, Trevor et al. 1996). These factors suggest that institutional theory may better explain current behavior. Resource-dependence (Pfeffer and Salancik 1978; Pfeffer 1990) and managerial power (Lambert, Larker et al. 1993; Werner and Tosi 1995) theories may also shed light on what accounts for the significant variance within and across organizations in the use of organization-wide variable pay.

From a practical perspective, these results suggest that managers should critically examine the reasons for engaging in these "innovative" compensation practices. The reality is 
that the performance-based rhetoric used to support these practices is not a complete explanation. Additional factors such as responding to competitors' practices in order to attract and retain people, following the latest trends regardless of any payoffs or maintaining internal equity may also explain the use of incentive plans.

\section{Conclusion}

Each theoretical perspective on its own gives limited insight into the variable compensation organization - performance relationship. Further research using theories that are institutionally and politically based may provide additional insight. Rational theory alone does not appear to explain the significant variation in use of short-term and long-term broad based incentives observed in practice. 
Table 1 Summary of Hypotheses

\begin{tabular}{|c|c|c|c|c|}
\hline Hypotheses & $\begin{array}{c}\text { Individual- } \\
\text { Level }\end{array}$ & Level-1 & Company-Level & Level-2 \\
\hline $\begin{array}{l}\text { H1a: Organizational performance is related to the use of variable pay. Higher performing } \\
\text { organizations are more likely to pay more variable compensation than poorer performing } \\
\text { organizations. }\end{array}$ & $\begin{array}{l}\text { Average } \\
\text { variable pay }\end{array}$ & $\beta_{0 j \mathrm{jj}}>0$ & $\begin{array}{l}\text { Organizational } \\
\text { Performance }\end{array}$ & $\gamma_{01}>0$ \\
\hline $\begin{array}{l}\text { H1b: Higher performing organizations are will to pay more variable compensation throughout } \\
\text { the organization than poorer performing organizations. }\end{array}$ & Job level & $\beta_{3 j}$ & $\begin{array}{l}\text { Organizational } \\
\text { Performance }\end{array}$ & $\gamma_{31}>0$ \\
\hline H1c: The proportion of variable pay to base pay will be positively related to job level. & Job level & $B_{3 j}<0$ & NA & NA \\
\hline $\begin{array}{l}\text { H1d: The degree of variability in organizational performance will be negatively related to the } \\
\text { proportion of variable pay to base pay, net of variations due to differences in job level. }\end{array}$ & $\begin{array}{c}\text { Average } \\
\text { variable pay }\end{array}$ & $B_{0 j}>0$ & Organizational Risk & $\gamma_{02}<0$ \\
\hline $\begin{array}{l}\text { H1e: The degree of variability in organizational performance moderates the effect of job level } \\
\text { on the proportion of variable pay to base pay such that for organizations with higher levels of } \\
\text { performance variability, the relationship between job level and variable pay to base will be } \\
\text { lower than for organizations with low levels of performance variability }\end{array}$ & Job Level & $B_{3 j}$ & Organizational Risk & $\gamma_{32}<0$ \\
\hline \multicolumn{5}{|l|}{ Positivist Agency Theory: } \\
\hline $\begin{array}{l}\text { H2a: The greater the levels of firm monitoring the smaller the proportion of variable pay to } \\
\text { base pay }\end{array}$ & Job level & $B_{3 j}<0$ & $\begin{array}{l}\text { Organizational } \\
\text { Size }\end{array}$ & $\gamma_{33}<0$ \\
\hline $\begin{array}{l}\text { H2b: Individuals in technical jobs are more likely to have greater proportions of variable pay } \\
\text { to base pay compared to non-technical jobs }\end{array}$ & Job Type & $B_{2 j}>0$ & NA & NA \\
\hline $\begin{array}{l}\text { H2c: Large companies will have lower proportions of variable pay to base pay than smaller } \\
\text { companies }\end{array}$ & $\begin{array}{l}\text { Average } \\
\text { variable pay }\end{array}$ & $\beta_{0 j}$ & $\begin{array}{l}\text { Organizational } \\
\text { Size }\end{array}$ & $\gamma_{03}<0$ \\
\hline
\end{tabular}

\begin{tabular}{|c|c|c|c|c|}
\hline Contingency Theory: & $\begin{array}{c}\text { Individual- } \\
\text { Level }\end{array}$ & $\begin{array}{c}\text { Level-1 } \\
\text { Coefficient }\end{array}$ & Company-Level & Level-2 Coefficient \\
\hline $\begin{array}{l}\text { H3: Individuals in young growth companies will have compensation } \\
\text { characterized by a high proportion of variable pay to base compared to } \\
\text { other companies }\end{array}$ & $\begin{array}{l}\text { Average } \\
\text { variable pay }\end{array}$ & $\beta_{0 j}$ & $\begin{array}{l}\text { Age, Organizational } \\
\text { strategy, and } \\
\text { Age } x \text { Organizational } \\
\text { strategy }\end{array}$ & $\begin{array}{l}\gamma_{04}<0 \\
\gamma_{05}>0 \\
\gamma_{06}<0\end{array}$ \\
\hline $\begin{array}{l}\text { H4: Young growth companies are less likely to have higher variable pay } \\
\text { than other companies }\end{array}$ & $\begin{array}{l}\text { Average } \\
\text { variable pay }\end{array}$ & $B_{0 j}$ & $\begin{array}{l}\text { Age, Organizational } \\
\text { strategy, and } \\
\text { Age x Organizational } \\
\text { strategy }\end{array}$ & $\begin{array}{l}\gamma_{04}>0 \\
\gamma_{05}<0 \\
\gamma_{06}>0\end{array}$ \\
\hline $\begin{array}{l}\text { H5: Organizational strategy moderates the proportion of variable pay such } \\
\text { that those managers in technical positions in young growth companies will } \\
\text { exhibit higher variable pay compared to other companies }\end{array}$ & Job Type & $B_{2 j}$ & $\begin{array}{l}\text { Age, Organizational } \\
\text { strategy, and } \\
\text { Age x Organizational } \\
\text { strategy }\end{array}$ & $\begin{array}{l}\gamma_{21}<0 \\
\gamma_{22}>0 \\
v_{23}<0\end{array}$ \\
\hline
\end{tabular}


Table 2

Means and Correlations

\begin{tabular}{|c|c|c|c|c|c|c|c|c|c|c|c|}
\hline & Mean & SD & & & & & & & & & \\
\hline Short-term variable & 0.101 & 0.114 & & & & & & & & & \\
\hline Long-term variable & 0.282 & 0.605 & 0.347 & & & & & & & & \\
\hline Tenure & 9.610 & 8.750 & 0.079 & -0.121 & & & & & & & \\
\hline Job type & 0.431 & 0.495 & 0.004 & 0.086 & -0.080 & & & & & & \\
\hline $\begin{array}{l}\text { Job Level } \\
\text { Organizational }\end{array}$ & 4.413 & 1.620 & -0.280 & -0.260 & -0.240 & -0.004 & & & & & \\
\hline Performance & 15.070 & 10.580 & 0.337 & 0.286 & -0.182 & 0.027 & 0.069 & & & & \\
\hline Organizational risk & 0.780 & 7.700 & -0.002 & 0.000 & -0.010 & 0.004 & -0.010 & 0.003 & & & \\
\hline Size & 35,619 & 39,917 & 0.208 & -0.049 & 0.163 & -0.090 & -0.002 & -0.032 & 0.010 & & \\
\hline Age & 44.61 & 34.40 & 0.035 & -0.180 & 0.217 & -0.090 & -0.020 & -0.243 & -0.030 & 0.620 & \\
\hline Organizational & 0.843 & 0.3630 & 0.175 & 0.093 & -0.050 & 0.015 & 0.060 & 0.226 & -0.060 & 0.240 & -0.170 \\
\hline Age x Org strategy & 35.60 & 34.34 & 0.119 & -0.096 & 0.108 & -0.050 & 0.030 & -0.166 & -0.030 & 0.710 & 0.730 \\
\hline
\end{tabular}

Correlations significant at $\mathrm{p}<.05$ for all values $>.01$ for $\mathrm{N}=398,239$ 


\section{Table 3 \\ Hierarchical Linear Model Regression on Short-term Bonus Pay}

Short-term variable to base pay intercept $\beta 0$

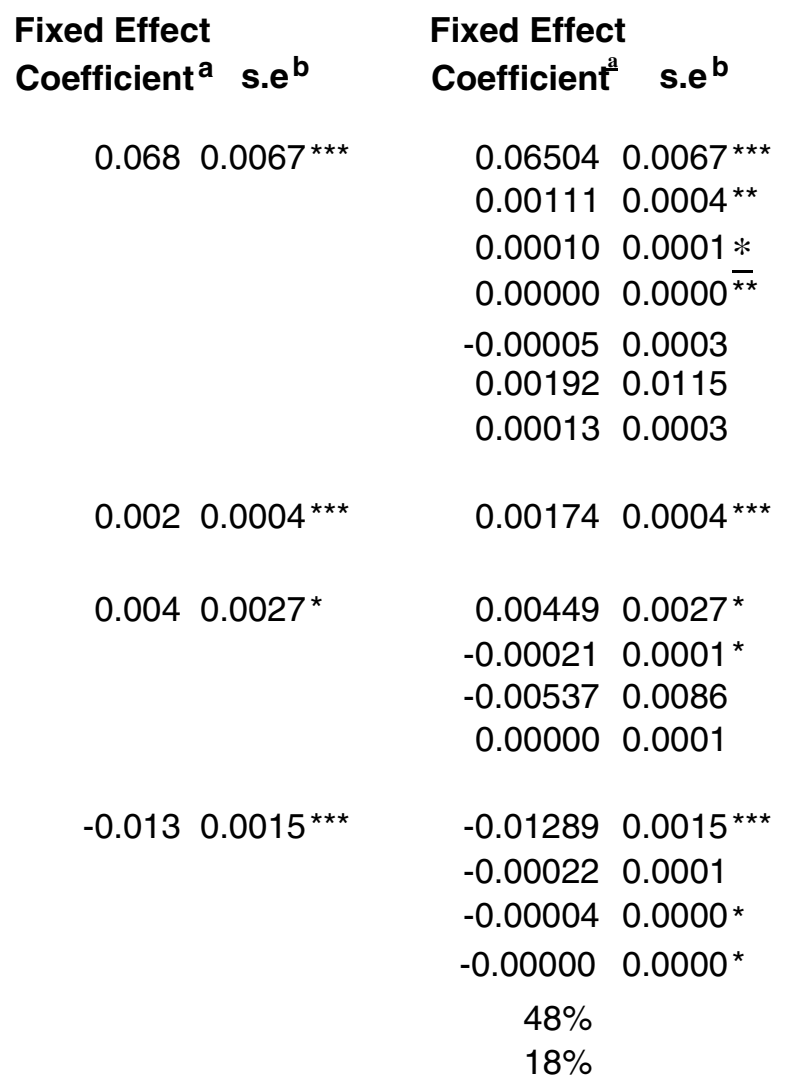

a Variables centered on their grand mean

b Robust standard errors

${ }^{*} \mathrm{p}<.05{ }^{* *} \mathrm{p}<.01{ }^{* \star *} \mathrm{P}<.001$ one-sided tails 
Table 4

Hierarchical Linear Model

Regression on Long-term Incentive Pay

Short-term variable to base pay intercept $\beta 0$

\section{Fixed Effect \\ Coefficient $^{a}$ s.e ${ }^{b}$}

Base $\gamma 00$

Organizational Performance $\gamma 01$

Organizational risk $\gamma 02$

Size $\gamma 03$

Age $\gamma 04$

Organizational strategy $\gamma 05$

Age $x$ Organizational strategy $\gamma 06$

Tenure $\beta 1$

Base $\gamma 10$

Technical job type $\beta 2$

Base $\gamma 20$

Age $\gamma 21$

Organizational strategy $\gamma 23$

Age $x$ Organizational strategy $\gamma 24$

Number of Hierarchical level $\beta 3$

Base $\gamma 30$

Performance $\gamma 31$

Performance risk $\gamma 32$

Size $\gamma 33$

$\%$ Individual-level variance

$\%$ Organization-level
$0.2250 .0390^{* * *}$

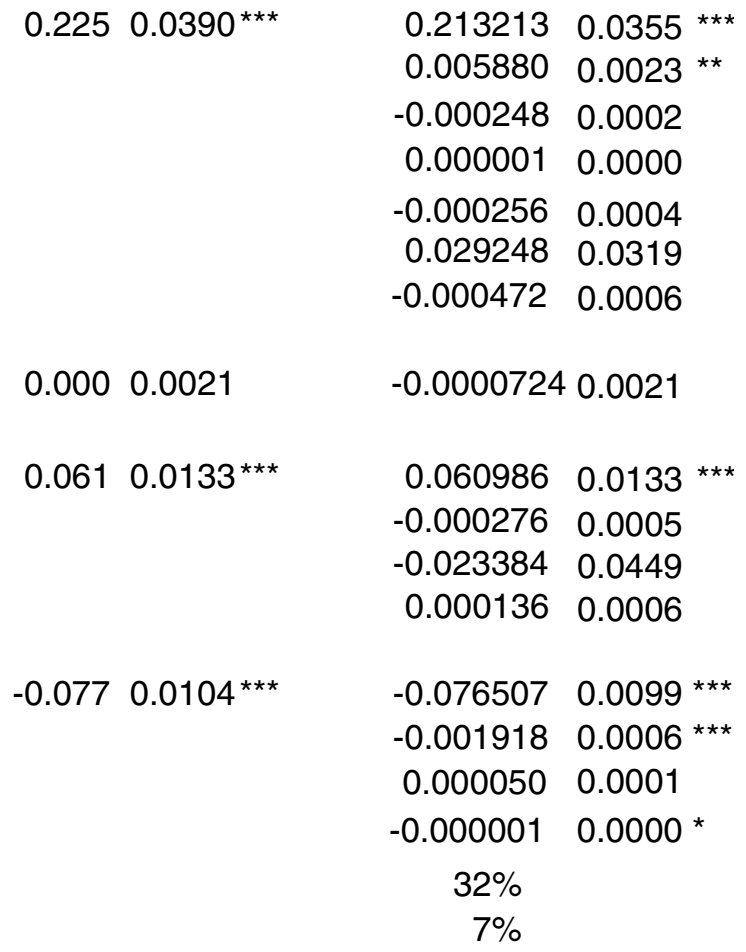

Fixed Effect

Coefficient $^{\mathrm{a}}$ s.e $\mathrm{e}^{\mathrm{b}}$

$0.2132130 .0355^{* * *}$

0.0058800 .0023 *

0.0002

$-0.000256 \quad 0.0004$

$0.029248 \quad 0.0319$

a Variables centered on their grand mean

b Robust standard errors

${ }^{*} p<.05{ }^{* *} p<.01{ }^{* \star *} P<.001$ one-sided tails 


\section{References}

Abosch, K. S. (1998). "Variable Pay: Do We Have the Basics in Place?" Compensation and Benefits Review: 12-22.

Abowd, J. (1990). "Does Performance-Based Managerial Compensation Affect Corporate Performance." Industrial and Labor Relations Review 43S: 52-73.

Aggarwal, R.K., \& Samwick, A.A. (1999). the Other Side of the Trade-off: The Impact of Risk on Executive Compensation. Journal of Political Economy, 107(1), 65-105.

Anderson, M. C., R. D. Banker, et al. (2000). "Executive Compensation in the Information Technology Industry." Management Science 46(4): 530-547.

Baker, G., R. Gibbons, et al. (1997). Implicit contracts and the theory of the firm. Cornell University. Ithaca.

Barney, J. (1991). "Firm Resources and Sustained Competitive Advantage." Journal of Management 17(1): 99-120.

Bartol, K. M., \& Locke, E. A. (2000). Incentives and Motivation. In S.L.. Rynes \& B. Gerhart (Eds.), Compensation in Organizations (pp. 104-150). San Francisco: Jossey-Bass.

Beatty, R.P., \& Zajac, E.J. (1994). Managerial incentives, monitoring, and risk bearing: a study of executive compensation, ownership, and board structure in initial public offerings. Administrative Science Quarterly, 39(2), 313-356.

Bloom, M., \& Milkovich, G. T. (1998). The relationship between risk, incentive pay, and organizational performance. Academy of Management Journal, 41(3), 283-297.

Boyd, B. K., \& Salamin, A. (2001). Strategic Reward Systems: a Contingency Model of Pay System Design. Strategic Management Journal, 22, 777-792.

Bryk, A. S. and S. W. Raudenbush (1992). Hierarchical Linear Models: Applications and Data Analysis Methods. Newbury Park.

Chingos, P. T., Ed. (1997). Paying for Performance: A Guide to Compensation Management. New York, John Wiley \& Sons, Inc.

Eisenhardt, K. M. (1989). "Agency Theory: An Assessment and Review." Academy of Management Review 14(1): 57-74.

Finkelstein, S. and B. K. Boyd (1998). "How much does the CEO matter? The role of managerial discretion in the setting of CEO compensation." Academy of Management Journal 41(2): 179-218.

Garen, J. E. (1994). Executive Compensation and Principal-Agent Theory. Journal of Political Economy, 102(6), 11775-1199.

Gerhart, B. and G. Milkovich (1990). "Organizational differences in managerial compensation and financial performance." Academy of Management Journal 33: 663-691.

Gerhart, B. and C. Trevor (1996). "Employment Variability Under Different Compensation Systems." Academy of Management Journal 39: 1692-1712.

Gerhart, B., C. Trevor, et al. (1996). "New Directions in Compensation Research: synergies, Risk, and Survival." Research in Personnel and Human Resources Management 14: 143-203.

Gomez-Mejia, L. and R. M. Wiseman (1997). "Reframing Executive Compensation: An Assessment and Outlook." Journal of Management 23(3): 291-374.

Gomez-Mejia, L. R. and D. B. Balkin (1992). Compensation, Organizational Strategy, and Firm Performance. Cincinnati, South-Western Publishing Co.

Gray, S., \& Jr., A. A. C. (1997). The role of risk in executive compensation. Journal of Management, 23(4), 517-541.

Grossman, S., \& Hart, O. (1983). an Analysis of the Principal-Agent Problem. Econometrica, $51,-35$.

Hall, B., \& Murphy, K. J. (2000). Stock Options for Undiversified Executives. Unpublished Negotiation, Organizations and Markets Research Paper 00-01, Harvard University, Cambridge. 
Hoffman, D. A. (1997). "Hierarchical Linear Models." Journal of Management 23(6): 723-744. Huselid, M. A. (1995). "The Impact of Human Resource Management Practices on Turnover, Productivity, and Corporate Financial Performance." Academy of Management Journal 38(3): 635-672.

Lambert, R., D. F. Larker, et al. (1993). "The Structure of Organizational Incentives.” ASQ 38: 438-461.

Leonard, J. (1990). Executive Pay and Firm Performance. Industrial and Labor Relations Review, 43, 13-29.

Levine, D. I. (1993). "What Do Wages Buy." ASQ.

Mehran, H. (1995). "Executive compensation structure, ownership and firm performance." Journal of Financial Economics 38: 163-184.

Milkovich, G. T. (1988). "A Strategic Perspective on Compensation.” Research in Personnel and Human Resources Management 6: 263-288.

Montemayor, E. F. (1996). "Congruence between Pay Policy and Competitive Strategy in HighPerforming Firms." Journal of Management 22(6): 889-908.

Pfeffer, J. (1990). Incentives in Organizations: The importance of social relations. Organization Theory: From Chester Barnard through the Present and Beyond. O. E. Williamson. New York, Oxford University Press: 72-97.

Pfeffer, J. and G. R. Salancik (1978). The External control of Organizations: A Resource Dependence Perspective. New York, Harper \& Row.

Pfeffer, J. and J. Veiga (1999). "Putting People First for Organizational Success." Academy of Management Executive 13(2): 37-48.

Porter, M. E. (1985). Competitive Advantage. New York, Free Press.

Ruefli, T. W., J. M. Collins, et al. (1999). "Risk Measures in Strategic Management Research: Auld Lang Syne?" Strategic Management Journal 20: 167-194.

Scott, R. (1995). Organizations. Englewood Cliffs, Prentice Hall.

Scott, W. R. (1992). Organizations: Rational, Natural and Open Systems. Englewood Cliffs, Prentice Hall.

Welbourne, T. and L. Gomez-Meija (1995). "Gainsharing: A Critical Review and A Future Research Agenda." Journal of Management 21(3): 559-609.

Werner, S. and H. Tosi (1995). "Other People's Money: the Effects of Ownership on Compensation Strategy and Managerial Pay." Academy of Management Journal 38(6): 1672-1691.

Williamson, O. (1981). "The Economics of Organization: The Transaction cost Approach.” ASJ: 548.

Wiseman, R. M., Gomez-Mejia, L., \& Fugate, M. (2000). Rethinking Compensation Risk. In S. Rynes \& B. Gerhart (Eds.), Compensation in Organizations (pp. 311-347). San Francisco: Jossey-Bass. 


\section{Endnotes}

' Other theories include institutional and resource-dependence theories. However, these theories are not included in this paper because they focus on institutional and political factors rather than organizational performance, which is the main issue being examined here.

ii Our different results may have been the result of using different measures of risk (Ruefli, 1999). However, when we used stock-based measures of risk, the Black-Scholes measure of stock volatility, our results were similar. 